\title{
Assessment of the Ground and Plant Chemistry in an Area Affected by Rare Metal Ore Concentration Waste Storage
}

Eugenia Krasavtseva ( $\sim$ vandeleur2012@yandex.ru )

KSC RAS: Kol'skij naucnyj centr Rossijskaa akademia nauk https://orcid.org/0000-0002-8821-4446

Viktoria Maksimova

KSC RAS: Kol'skij naucnyj centr Rossijskaa akademia nauk

Tamara Gorbacheva

KSC RAS: Kol'skij naucnyj centr Rossijskaa akademia nauk

\section{Research}

Keywords: ore processing waste, rare metals, bulk analysis, enrichment factor, biological absorption coefficient, Salix spp., Avenella flexuosa L.

Posted Date: May 5th, 2021

DOI: https://doi.org/10.21203/rs.3.rs-406947/v1

License: (c) (i) This work is licensed under a Creative Commons Attribution 4.0 International License. Read Full License 


\section{Abstract}

This paper presents the results of an assessment of the ground and plant chemistry in disturbed areas exposed to impacts from adjacent rare metal ore concentration waste storage facilities.

The focus of research were areas with sparse vegetation cover near the site of the first tailing storage facility (TSF), which is not exploited from 1985. In the summer of 2019 , on three key plots within the study area, plant samples were collected at a small distance from the TSF and operating process transport routes $(<1 \mathrm{~km})$.

Based on a bulk chemistry analysis of the ground samples, concentration values were measured above the background values adopted for the region's soil parent rock materials, and in the absence thereof, the clarkes of elements in acidic $\left(\mathrm{SiO}_{2}>60 \%\right)$ rocks found in the earth's crust. Grounds were found to be rich in $\mathrm{Ta}, \mathrm{Ce}, \mathrm{La}, \mathrm{Th}, \mathrm{Zr}, \mathrm{Nb}$, which are also present in the loparite ores of various origins mined by the operation.

The chemistry was examined of Salix spp. commonly found both in the study area and in the region as a whole and of wavy hair grass Avenella flexuosa L. An abnormally high level of zinc accumulation was observed in Salix lapponum (>850 mg/kg, biological absorption coefficient (BAC) $>4$ ), and technological transport influence was proposed as a possible cause. High paired correlation coefficients of rare and trace elements with $\mathrm{Al}$ and with each other (>0.9) in the bulk chemistry analysis of Salix spp. indicate the likelihood of deposition of minerogenetic dust particles. Based on the observed values of the BAC, the plants were classified into biological accumulation $(B A C>1)$ and biological uptake $(B A C<1)$ classes and the latter was found to be dominant.

\section{Introduction}

Mining and processing of rare metal ores is accompanied by the formation of a significant amount of liquid and solid waste, including gangue rock, tailings, sludge, and wastewater (Edahbi et al. 2019). For instance, in the production of 1 ton of rare earth elements (REE) in China, which is the world's leading producer and exporter of REE (94\% (Geological Survey 2020)), approximately $8.5 \mathrm{~kg}$ of fluorite, $13 \mathrm{~kg}$ of dust, 9600 to 12000 tons of mining waste, 75 cubic meters of acidic water, and one ton of radioactive waste is generated (Rodzkin et al. 2019; Schlinkert and Van den Boogaart 2015; Hurst 2010).

Active deposits and mining and processing waste storage facilities can pose a serious threat to the environment in the form of elevated REE concentrations in the air, water, and soil, especially in the area of mining operations (Huang et al. 2016; Schreiber et al. 2016; Wang et al. 2014).

Poorer quality and changes in the chemical composition of air are caused by REE emissions into the atmosphere in gaseous form or in the form of atmospheric aerosols (Stille et al. 2009; Wang et al. 2014). Non-stabilized waste dumps and waste storage sites, capable of spreading dust over long distances, are also a source of fine particulate matter in the air (Csavina et al. 2012; Masloboev et al. 2016). These fine particles are capable of causing respiratory and cardiovascular diseases, severe intestinal disorders, keratosis, and skin cancer (Cheng et al. 2013).

Primary soil formation on tailings storage sites of the rare metals industry is poorly studied. It is known that after entering the soil, REEs can be adsorbed, since organic matter is a source of negatively charged particles in weathered soils (Beckwith and Butler 1993). However, REEs affinity to humic substances varies, and exposure to dissolved organic matter may initiate the reverse process of desorption (Xiangke et al. 2000). The REE concentration in the soil solution is directly correlated with the content of dissolved organic carbon and inversely with the soil pH (Pourret et al. 2007; Tang and Johannesson 2010). In general, the behavior of REEs in soils is similar to that of heavy metals (Ramos et al. 2016). The greatest risk arising from an increase in the REE influx into terrestrial ecosystems due to anthropogenic impacts is observed in countries with soils naturally high in REEs, including Russia (Thomas et al. 2013).

Plants growing in areas close to mining operations are contaminated both as a result of dusting and as a result of the uptake of REEs and heavy metals from the soil. Unlike heavy metals, the phytotoxicity of REEs has not yet been sufficiently studied (Thomas et al. 2013). It is known that the concentration of light REEs in the roots of vascular plants is usually higher than in other plant organs, including shoots (Carpenter et al. 2015; Grosjean 2019; Mikołajczak et al. 2017; Nazreen et al. 2017; Thomas et al. 2013). However, the accumulation of these in leaves and stems, being the main organs of photosynthesis, can have major consequences for plant growing (Thomas et al. 2013).

At the same time, effective REE transport from the root system to the leaves is one of the most important criteria in an effective phytoextraction strategy: with the active accumulation of REEs in the aboveground parts of plants, these are easily removed from the environment (Mikołajczak et al. 2017).

Research on abandoned wastelands has shown that Poaceae are the dominant plant family there (Mishra et al. 2017; Singh 2011). These grasses have an extensive root system, which supports the rapid colonization of abandoned lands (Chauhan and Ganguly 2011; Mishra et al. 2017; Singh et al. 2013). A number of studies present the results of phytoremediation of disturbed lands by planting willows that absorb heavy metals, in particular arsenic, cadmium, lead, zinc (Tlustoš et al. 2007; Borišev et al. 2009; Rodzkin et al. 2019; Salam et al. 2019).

The purpose of this work is to assess the level of biological accumulation of the main and accompanying elements of the enrichment of rare metal waste in the area adjacent to the unexploited field of the tailing dump of the mining enterprise, for a preliminary detailed assessment of the suitability of grounds for the phytoremediaton by Poaceae and Salix.

\section{Materials And Methods}

Mineral loparite (Ce, $\mathrm{Na}, \mathrm{Sr}, \mathrm{Ca})(\mathrm{Ti}, \mathrm{Nb}, \mathrm{Ta}, \mathrm{Fe}) \mathrm{O}_{3}$ is the main light rare earth element (LREE) ore in Russia (Hedrick et al., 1997). The only Russian enterprise that develops a deposit of loparite ores, located in the center of the Kola Peninsula, and extracts niobium, tantalum, and rare earth elements of the cerium group (Ce, Pr, Nd, Pm). Enrichment of loparite ores takes place in three stages. A rough concentrate is obtained by the gravity method with a sequential stage 
reduction in the size of crushed ore, based on the difference in density between the main mineral - loparite and rock-forming minerals (its density is 1.7-2 times higher than the main rock-forming minerals, represented by feldspar, nepheline and aegirine). This is followed by the cleaning stage - apatite flotation department. At the stage of finishing, light-colored minerals (nepheline, feldspar, aegirine) are removed using electrostatic and electromagnetic separation.

During the period of operation of the first TSF site (1951-1985), the amount of ore concentration waste accumulated by the operation reached 6.7 million tons (Mesyats and Ostapenko, 2013). From 1985 to the present, tailings have been discharged to the second site of the mining operations tailings storage facility.

The study area is the industrial site of mining enterprise in the immediate vicinity of the first TSF and process transport routes (Fig. 1). In the summer of 2019, ground samples were collected in the study area at three key locations. Samples were collected at a depth of 0-20 cm in accordance with the requirements of GOST 17.4.3.01-83. The collected samples were brought to an air-dry state and sieved through a $2 \mathrm{~mm}$ sieve.

Simultaneously with the sampling of grounds at the selected locations, three replicates of plant samples was collected. Plants of two genera were selected for the bulk analysis - wavy hair grass Avenella flexuosa L., and woody plants of the willow genus Salix. S. phylicifolia, S. lapponum, and S. glauca. Willow leaves and the aboveground part of wavy hair grass were sampled in accordance with the international sampling guidelines for the ground vegetation cover to study the effect of air pollution on forest ecosystems (Manual..., 2007).

Bulk analysis after acid decomposition of the ground samples was carried out by inductively coupled plasma mass spectrometry (measuring instrument ELAN 9000 by PerkinElmer, USA) at the Shared Use Centre, Institute of Industrial Ecology of the North, Kola Science Centre at the Russian Academy of Sciences (INEP KSC RAS). This paper presents weighted average values of bulk ground chemistry.

Plant samples weighing 500 mg were placed in polypropylene tubes, to which concentrated $\mathrm{HNO}_{3}$ was added. The mixture was kept in closed test tubes for 12 hours. Then the contents were transferred to the liners of DAC-100 autoclaves, placed in the microwave system MW 4 and decomposed in a single cycle ( 90 min). The solutions were returned to the test tubes and diluted to the mark with a $2 \% \mathrm{HNO}_{3}$ solution. Bulk analysis of the plant samples was performed using an ELAN 9000 DRC-e inductively coupled plasma mass spectrometer (by Perkin Elmer, USA) at ICTREMR, KSC RAS. To tune the instrument, we used a Multielement ICP-MS Calibration Standard STD 1 sample (by Perkin Elmer); to calibrate the instrument, we used standard solutions ICP-MS Calibration Standard IVSTOCK-21, IV-STOCK-26, IV-STOCK-28, IV-STOCK-29 (by Inorganic Ventures, USA) with a mass concentration of the measured elements of 10 mg/dm ${ }^{3}$ and a measurement error not exceeding $0.5 \%$ at $\mathrm{P}=0.95$.

A quality check of plant analysis was carried out on the basis of the present control standards which are to be linked with the International Co-operative Program on Assessment and Monitoring of Air Pollution Effects on Forests (operated by the United Nations Economic Commission for Europe) (Furst 2019).

Based on the bulk ground chemistry analysis, the enrichment factor $\mathrm{K}_{\mathrm{o}}$ was calculated as the ratio of the concentration of the target element $\mathrm{C}_{\mathrm{i}}$ to its content in the parent rock $C_{P}: K_{o}=C_{i} / C_{P}$ (Nikonov et al. 2004; Kabata-Pendias 2011). Gross content of the element in the $C$ horizon of the region's native soils was taken as the background value (Nikonov et al. 2004). In the absence of background values, the comparison was based on the clarke content of the element in the earth's crust, determined for acid $\left(\mathrm{SiO}_{2}>60 \%\right)$ rocks as described in (Vinogradov 1962).

Based on the results of the bulk chemistry analysis of plants and ground, the biological absorption coefficient (BAC) was calculated as the ratio of the total content of an element in the plant material to its total content in the ground. Then the studied plants were classified into two groups: biological accumulation group (BAC>1) and biological capture group (BAC< 1) (Avessalomova 1987; Perelman 1979).

To identify minerogenic particles in the dust deposited on the leaf blade, a correlation analysis was carried out of the bulk chemistry of the vegetative organs of Salix spp. Identification was carried out based on statistically significant correlation of the given element with the reference element aluminum (Reimann et al. 2001), as the most common (along with oxygen and silicon) element in the earth's crust.

\section{Results And Discussion Ground chemistry}

The gross content of elements in the grounds $(n=9)$, plants, clarke and background values for the study area are shown in Table 1. No pronounced differences in the bulk ground chemistry under vegetation cover in the sampled area and that of the tailings on the first TSF site (Krasavtseva 2020) were found for the measured elements, which suggests that these originate from same source. The current variability of the chemical composition can be explained by the differentiation of the particle size distribution of the tailings over a long period after the TSF was decommissioned. 
Table 1

Gross content of the measured elements in grounds and plants, $\mathrm{mg} / \mathrm{kg}$

\begin{tabular}{|c|c|c|c|c|c|c|c|}
\hline Element & $\begin{array}{l}\text { Grounds } \\
(n=9)\end{array}$ & Background value * & Clarke content ** & S. phylicifolia & S. lapponum & S. glauca & Avenella flexuosa $\mathrm{L}$. \\
\hline $\mathrm{Ni}$ & 13.9 & 42 & 8 & 3.7 & 4.2 & 3.8 & 8.3 \\
\hline $\mathrm{Cu}$ & 21.5 & - & 20 & 8.8 & 15.3 & 10.1 & 6.2 \\
\hline $\mathrm{Sr}$ & 2172.7 & 310 & 300 & 386.6 & 332.4 & 563.5 & 138.8 \\
\hline $\mathrm{Zn}$ & 198.7 & 32 & 60 & 595.1 & 856.6 & 560.2 & 118.9 \\
\hline $\mathrm{Mn}$ & 1385.9 & - & 600 & 214.6 & 161.1 & 314.1 & 118.8 \\
\hline La & 805.9 & 4.8 & 60 & 2.7 & 7.5 & 7 & 8.3 \\
\hline $\mathrm{Ce}$ & 1576.5 & 8.4 & 100 & 4.6 & 13.2 & 12.7 & 16 \\
\hline $\operatorname{Pr}$ & 176.3 & - & 12 & 0.3 & 1.1 & 1.1 & 1.5 \\
\hline $\mathrm{Nd}$ & 570.9 & - & 46 & 1.2 & 3.4 & 3.4 & 4.4 \\
\hline $\mathrm{Ba}$ & 242.5 & 246.5 & 830 & 4.6 & 31.2 & 24.3 & 13.6 \\
\hline V & 44.2 & 37 & 40 & 3.7 & 3.7 & 4 & 4.1 \\
\hline $\mathrm{Ti}$ & 6081.5 & - & 2300 & 9.1 & 34.4 & 22.4 & 30.9 \\
\hline $\mathrm{Rb}$ & 193.2 & 54 & 200 & 33.1 & 21.7 & 44.3 & 31.4 \\
\hline Th & 164.6 & 1.5 & 18 & 0.2 & 0.7 & 0.6 & 0.7 \\
\hline $\mathrm{U}$ & 11.3 & 0.8 & 3.5 & 0.1 & 0.1 & 0.1 & 0.1 \\
\hline $\mathrm{Ta}$ & 94.3 & 0.1 & 3.5 & 0 & 0.2 & 0.1 & 0 \\
\hline $\mathrm{Nb}$ & 944.4 & - & 20 & 1.5 & 4.7 & 3.4 & 4.1 \\
\hline $\mathrm{Zr}$ & 1896.1 & 28.5 & 200 & 2.5 & 8.2 & 9.0 & 10.4 \\
\hline Al & 108193 & - & 77000 & 116.4 & 382.2 & 477 & 675 \\
\hline $\mathrm{Mg}$ & 2329 & - & 5600 & 1695.4 & 1465.1 & 1602.4 & 1285.5 \\
\hline $\mathrm{Ca}$ & 9045 & - & 15800 & 3079.1 & 5355.8 & 3881.7 & 1833 \\
\hline $\mathrm{Fe}$ & 43262 & 14600 & 27000 & 135.7 & 237.1 & 102.6 & 152.4 \\
\hline
\end{tabular}

Note: * - data from (Nikonov et al. 2004);

** - data from (Vinogradov 1962).

The results of the bulk chemistry analysis of the grounds indicate that these are significantly enriched in all elements making up the minerals of the nephelinesyenite pegmatite deposit of the Lovozero rock mass. The enrichment factors are shown in Fig. 2, where the elements are sorted in descending order in terms of $\mathrm{K}_{\mathrm{o}}$. The highest $\mathrm{K}_{\mathrm{o}}$ values were found for $\mathrm{Ta}, \mathrm{Ce}, \mathrm{La}, \mathrm{Zr}, \mathrm{Nb}$. Elevated levels of uranium and thorium in the grounds are evident. For essential plant nutrients, such as $\mathrm{Ca}$ and $\mathrm{Mg}$, ground depletion was observed when compared to the clarke values.

\section{Plant chemistry}

is presented in Table 1.

A comparison was made of the data obtained with the average values of the gross content of a wide range of elements in Salix spp. growing in the European Arctic (Reimann et al. 2001). The results indicate that woody plants face a deficiency of the available forms of such nutrients as Ca, Mg, Mn. The gross content of $\mathrm{Cu}, \mathrm{Ni}, \mathrm{Ba}, \mathrm{Rb}, \mathrm{Fe}$ in the vegetative organs of willows is within the natural variability range typical of high latitudes. The accumulation of $\mathrm{Al}$, Th, $\mathrm{U}$, $\mathrm{V}$, $\mathrm{Zr}, \mathrm{Zn}$, Sr by willows is obvious compared to the species' northern European range.

The biological absorption coefficients of most elements in the study area are less than 1, which indicates very low reserves of their bioavailable forms. This can be attributed to the coarse grounds and the resistance of ground minerals to weathering, including when exposed to plant root exudates.

Figure 3 shows the biological absorption coefficients of those elements, for which a relatively high accumulation level in the vegetative organs of Salix spp. and is Avenella flexuosa L. was found (>100 mg/kg). Abnormal zinc accumulation is characteristic of Salix spp., which makes it possible to classify these tree species as belonging to the biological accumulation group. The gross zinc content in the vegetative organs of Salix spp. individuals varied between 560.2 and $856.6 \mathrm{mg} / \mathrm{kg}$. The highest level of zinc accumulation was found in Salix lapponum (BAC 4.31). Avenella flexuosa L. is classified in the biological capture group with a weak ability to accumulate $\mathrm{Zn}$. 
The high level of zinc accumulation in willow leaves can be associated with the effects of technological transport. For instance, (Avdoshchenko and Klimova $2020 \mathrm{a}, \mathrm{b}$ ) showed the indicator role of willows in the monitoring of zinc and lead pollution in urban areas with maximum accumulation levels in areas with heavy traffic. Dust deposition of zinc on roadside vegetation is associated with the wear of tires containing zinc (Konczak et al. 2021).

With the observed low root absorption values of most elements, as indicated by the low BAC values in willows, clear differences in their chemical composition from European reference values indicate the impact of dust deposition on the vegetation cover in the study area. The reason may be the transfer of the fine waste fraction accumulated in the tailings storage facility. Based on the data on the current particle size distribution of the ore concentration waste stored at the first site of the TSF (Goryachev et al. 2020), it was concluded that their surface layer should be classified as fine and medium-grained sands with a dusting during summer period.

Identification of dry deposition of dust particles on the willow leaf blade was carried out in this study based on the statistical significance of the "measured element - Al" correlation based on the results of the bulk chemistry analysis of willow leaves (Reimann et al. 2001). Correlation analysis data are shown in Table 2 .

Table 2

Correlation of elements in the bulk chemistry of Salix spp. leaves

\begin{tabular}{|c|c|c|c|c|c|c|c|c|c|c|c|c|c|c|c|c|c|c|c|}
\hline & $\mathrm{Ni}$ & $\mathrm{Cu}$ & Sr & $Z n$ & Mn & $\mathrm{La}$ & $\mathrm{Ce}$ & Pr & Nd & $\mathrm{Ba}$ & V & $\mathrm{Ti}$ & $\mathrm{Rb}$ & Th & $\mathbf{U}$ & $\mathrm{Ta}$ & $\mathrm{Nb}$ & $\mathrm{Zr}$ & $\mathbf{N}$ \\
\hline $\mathrm{Ni}$ & 1 & 0.03 & 0.60 & 0.56 & 0.65 & 0.15 & 0.10 & 0.13 & 0.12 & 0.14 & -0.90 & 0.33 & 0.50 & 0.05 & -0.36 & -0.31 & 0.12 & 0.09 & 0 \\
\hline $\mathrm{Cu}$ & & 1 & -0.49 & 0.73 & -0.01 & 0.22 & 0.24 & 0.26 & 0.24 & 0.65 & 0.01 & -0.19 & -0.03 & 0.26 & -0.43 & 0.75 & 0.32 & 0.31 & 0 \\
\hline $\mathrm{Sr}$ & & & 1 & -0.22 & 0.65 & 0.47 & 0.44 & 0.46 & 0.48 & 0.18 & -0.40 & 0.17 & 0.42 & 0.38 & 0.36 & -0.42 & 0.31 & 0.44 & 0 \\
\hline $\mathrm{Zn}$ & & & & 1 & 0.12 & -0.05 & -0.09 & -0.05 & -0.07 & 0.28 & -0.45 & 0.33 & 0.33 & -0.11 & -0.79 & 0.26 & -0.04 & -0.01 & 0 \\
\hline $\mathrm{Mn}$ & & & & & 1 & 0.15 & 0.20 & 0.22 & 0.23 & 0.27 & -0.63 & -0.35 & 0.63 & 0.17 & -0.09 & -0.37 & 0.19 & 0.21 & 0 \\
\hline $\mathrm{La}$ & & & & & & 1 & 0.99 & 0.99 & 0.99 & 0.86 & 0.06 & -0.06 & -0.28 & 0.98 & 0.61 & 0.60 & 0.94 & 0.97 & $-c$ \\
\hline $\mathrm{Ce}$ & & & & & & & 1 & 0.999 & 0.999 & 0.88 & 0.08 & -0.18 & -0.29 & 1.00 & 0.64 & 0.61 & 0.95 & 0.97 & $-c$ \\
\hline $\mathrm{Pr}$ & & & & & & & & 1 & 0.999 & 0.89 & 0.07 & -0.14 & -0.23 & 0.99 & 0.60 & 0.60 & 0.94 & 0.98 & $-c$ \\
\hline $\mathrm{Nd}$ & & & & & & & & & 1 & 0.88 & 0.08 & -0.14 & -0.21 & 0.98 & 0.60 & 0.58 & 0.93 & 0.99 & $-c$ \\
\hline $\mathrm{Ba}$ & & & & & & & & & & 1 & 0.02 & -0.28 & -0.13 & 0.88 & 0.26 & 0.76 & 0.87 & 0.90 & $-c$ \\
\hline V & & & & & & & & & & & 1 & -0.06 & -0.29 & 0.08 & 0.33 & 0.35 & -0.06 & 0.16 & $-c$ \\
\hline $\mathrm{Ti}$ & & & & & & & & & & & & 1 & 0.22 & -0.24 & -0.31 & -0.21 & -0.31 & -0.10 & 0 \\
\hline $\mathrm{Rb}$ & & & & & & & & & & & & & 1 & -0.36 & -0.58 & -0.58 & -0.45 & -0.11 & 0 \\
\hline Th & & & & & & & & & & & & & & 1 & 0.66 & 0.65 & 0.97 & 0.95 & $-c$ \\
\hline U & & & & & & & & & & & & & & & 1 & 0.21 & 0.62 & 0.52 & $-c$ \\
\hline $\mathrm{Ta}$ & & & & & & & & & & & & & & & & 1 & 0.68 & 0.60 & $-c$ \\
\hline $\mathrm{Nb}$ & & & & & & & & & & & & & & & & & 1 & 0.87 & $-c$ \\
\hline $\mathrm{Zr}$ & & & & & & & & & & & & & & & & & & 1 & $-c$ \\
\hline $\mathrm{Mg}$ & & & & & & & & & & & & & & & & & & & 1 \\
\hline \multicolumn{20}{|l|}{$\mathrm{Ca}$} \\
\hline $\mathrm{Fe}$ & & & & & & & & & & & & & & & & & & & \\
\hline $\mathrm{Al}$ & & & & & & & & & & & & & & & & & & & \\
\hline
\end{tabular}

High correlation ( $n=9$ ) was noted with Al as a reference element for the following elements: La, Ce, Pr, Nd, Zr, Nb with statistically insignificant correlations with other elements. Within the group of elements closely related to Al, strong relationships have also been noted. The revealed features indicate the presence of dust particles of mineral origin from local sources on the leaf blades of the plant samples. To corroborate this finding, the program of further research provides for the installation of bulk deposition collectors and identifying dust mineralogy by examining the filter residue.

Generally, plants growing in the study area are characterized by a low accumulation of the primary and secondary elements found in the ore concentration waste, which makes it possible to recommend these species for creating a sustainable man-made vegetation cover in the disturbed area. Based on our analysis of the collected data, one of the areas for further research will be to assess the compatibility of loparite ore concentration wastes with phytoremediation as a very promising, cost-effective solution that not only removes pollutants from the environment, but also helps restore lost biodiversity (Moosavi and Seghatoleslami 2013; Abdelsalam et al. 2019).

\section{Conclusion}


1. In the study area disturbed by a rare metal ore concentration tailings storage facility, elevated ground levels of $\mathrm{Ta}, \mathrm{Ce}, \mathrm{La}, \mathrm{Th}, \mathrm{Zr}$, $\mathrm{Nb}$ present in the mined loparite ores of different genesis were found.

2. High pair correlation coefficients of rare metals with Al and with each other $(r>0.9)$ in the leaves of Salix spp. indicate the likelihood of deposition of minerogenic dust particles, which finding requires field verification by installing sediment collectors and conducting a mineralogical analysis of the filter sediment.

3. Plants growing in the study area are characterized by a low accumulation of the primary and secondary elements found in the ore concentration waste, which makes it possible to recommend these species for creating a sustainable man-made vegetation cover in the disturbed area.

\section{Declarations}

Funding This study was carried out as part of the research project 0226-2019-0011 and partially funded by the grant 19-05-50065 Microcosm and by the Kolarctic CBC 2014-2020 programme, Project No. KO 1030 "Supporting Environmental Economic and Social Impacts of Mining Activity".

\section{Acknowledgements}

The authors are grateful to A.V. Timokhin and A.A. Cherepanov for their assistance in the collection of ground samples.

Conflicts of interest/Competing interests The authors declare that they have no conflict of interest. The founding sponsors had no role in the design of the study; in the collection, analyses, or interpretation of data; in the writing of the manuscript; or in the decision to publish the results.

Author contribution: Methodology, formal analysis, investigation - E.K., V.M., T.G.; writing review and editing - E.K., V.M., T.G.; funding acquisition, E.K. All authors have read and agreed to the published version of the manuscript.

Availability of data and material Not applicable

Code availability Not applicable

Animal research Not applicable

Consent to participate Not applicable

Consent to publish Not applicable

\section{References}

1. Aamlid, D., Canullo, R., \& Starlinger, F. (2007). Manual on methods and criteria for harmonized sampling, assessment, monitoring and analysis of the effects of air pollution on forests. Part VIII, Assessment of Ground Vegetation. Expert Panel on Ground Vegetation Assessment, UN-ECE, ICP-Forests.

2. Abdelsalam, I. M., Elshobary, M., Eladawy, M. M., \& Nagah, M. (2019) Utilization of Multi-Tasking Non-Edible Plants for Phytoremediation and Bioenergy Source-A Review. Phyton-International Journal of Experimental Botany, https://doi.org/10.32604/phyton.2019.06831.

3. Avdoshchenko, V.G., Klimova, A.V. (2020) The content of lead in the soil and vegetation cover of the territory of Petropavlovsk-Kamchatsky. Natural resources, their current state, protection, industrial and technical use. Materials of the XI National (All-Russian) Scientific and Practical Conference, https://doi.org/10.24411/9999-019A-2020-00023. (in Russian).

4. Avdoshchenko, V. and Klimov, A. (2020) Zinc content in soil and vegetable cover territories of Petropavlovsk-Kamchatsky. Development of theory and practice of management of social and economic systems, https://doi.org/10.24411/9999-026A-2020-00019. (in Russian).

5. Avessalomova, I. (1987) Geochemical Indicators In The Study Of Landscapes: Study Guide. Moscow: Izdatel'stvo Moskovskogo Universiteta. (in Russian).

6. Beckwith, R., Butler, J. (1993) Aspect of the chemistry of soil organic matter. Soil, an Australian viewpoint. Vic CSIRO/Academic Press.

7. Borišev, M., Pajević, S., Nikolić, N., Pilipović, A., Krstić, B., Orlović, S. (2009) Phytoextraction of Cd, Ni, and Pb using four willow clones (Salix spp.). J. Environ. Stud. 18 (4), 553-561.

8. Carpenter, D., Boutin, C., Allison, J., Parsons, J., Ellis, D. (2015). Uptake and Effects of Six Rare Earth Elements (REEs) on Selected Native and Crop Species Growing in Contaminated Soils, PloS one, https://doi.org/10.1371/journal.pone.0129936.

9. Chauhan, S., \& Ganguly, A. (2011) Standardizing rehabilitation protocol using revegetation cover for bauxite waste (red mud) in eastern India. Ecological Engineering, https://doi.org/10.1016/j.ecoleng.2010.12.017.

10. Cheng, Z., Jiang, J., Fajardo, O., Wang, S., Hao, J. (2013) Characteristics and health impacts of particulate matter pollution in China. Atmospheric Environment, https://doi.org/10.1016/j.atmosenv.2012.10.022.

11. Csavina, J., Field, J., Taylor, M.P., Gao, S., Landázuri, A., Betterton, E.A. et al. (2012) A review on the importance of metals and metalloids in atmospheric dust and aerosol from mining operations. Sci Total Environ, https://doi.org/10.1016/j.scitotenv.2012.06.013.

12. Edahbi, M., Plante, B., Benzaazoua, M. (2019) Environmental challenges and identification of the knowledge gaps associated with REE mine wastes management. Journal of Cleaner Production, https://doi.org/10.1016/j.jclepro.2018.11.228.

13. Fürst, A. (2019) 21th Needle/Leaf Interlaboratory Comparison Test 2018/2019. Technical Report QA-RFoliar19. International Cooperative Programme on Assessment and Monitoring of Air Pollution Effects on Forests (ICP-Forests). 
14. Goryachev, A., Lashchuk, V., Krasavtseva, E., Alfert'ev, N. and Makarov, D. (2020) Geoecological assessment of the current state of tailing dumps of different ages at the Karnasurt mine. Proceedings of the Fersman Scientific Session of the State Institute of the KSC RAS, https://doi.org/ 10.31241/FNS.2020.17.023. (in Russian).

15. GOST 17.4.3.01 - 83. (2008) Nature Conservancy (SSOP). Soils. General requirements for sampling. Moscow. (in Russian).

16. Grosjean, N., Le Jean, M., Berthelot, C. et al. (2019) Accumulation and fractionation of rare earth elements are conserved traits in the Phytolacca genus. Sci Rep., https://doi.org/10.1038/s41598-019-54238-3.

17. Hedrick, J., Sinha, S. and Kosynkin, V. (1997) Loparite, a rare-earth ore (Ce, Na, Sr, $\mathrm{Ca})(\mathrm{Ti}, \mathrm{Nb}, \mathrm{Ta}, \mathrm{Fe}+3)$ O3. Journal of Alloys and Compounds, https://doi.org/10.1016/S0925-8388(96)02824-1.

18. Huang, X., Deng, H., Zheng, C., Cao, G. (2016) Hydrogeochemical signatures and evolution of groundwater impacted by the Bayan Obo tailing pond in northwest China. Science of The Total Environment, https://doi.org/10.1016/j.scitotenv.2015.10.150.

19. Hurst, C., 2010 China's Rare Earth Elements Industry: what Can the West Learn? Institute for the Analysis of Global Security, Washington DC.

20. Kabata-Pendias, A. (2011) Trace Elements In Soils And Plants. London: CRC Press.

21. Kończak, B., Cempa, M., Pierzchała, Ł. and Deska, M. (2021) Assessment of the ability of roadside vegetation to remove particulate matter from the urban air. Environmental Pollution, https://doi.org/10.1016/j.envpol.2020.115465.

22. Krasavtseva, E. (2020) Assessment of the impact of the loparite ore enrichment waste storage on the environment. Mineralogy of technogenesis, 21, 163170. (in Russian).

23. Masloboev, V., Baklanov, A. and Amosov, P. (2016) Results of evaluation of tailing dumps dust intensity. Vestnik MGTU, https://doi.org/10.21443/15609278-2016-1/1-13-19. (in Russian).

24. Mesyac, S. and Ostapenko, S. (2013) Methodical approach to assessing the intensity of chemical weathering of mineral raw materials from technogenic deposits. Bulletin of the Murmansk State Technical University, 16(3), 566-572. (in Russian).

25. Mikołajczak, P., Borowiak, K., Niedzielski, P. (2017). Phytoextraction of rare earth elements in herbaceous plant species growing close to roads. Environmental Science and Pollution Research, https://doi.org/10.1007/s11356-017-8944-2.

26. Mishra, T., Pandey, V. C., Singh, P., Singh, N. B., \& Singh, N. (2017) Assessment of phytoremediation potential of native grass species growing on red mud deposits. Journal of Geochemical Exploration, https://doi.org/10.1016/j.gexplo.2016.12.015.

27. Mishra, T., Pandey, V.C., Praveen, A. et al. (2020) Phytoremediation ability of naturally growing plant species on the electroplating wastewatercontaminated site. Environ Geochem Health, https://doi.org/10.1007/s10653-020-00529-y.

28. Moosavi, S.G., Seghatoleslami, M.J. (2013) Phytoremediation: a review. Agric. Biol. 1 (1), 5-11.

29. Nazreen, M., Amalina, A., Omar, M. (2017). Bioaccumulation of Rare Earth Element by Water Lettuce (Pistia stratiotes). Oriental Journal of Chemistry, https://doi.org/10.13005/ojc/330305.

30. Nikonov, V., Lukina, N., Bezel', V. S. et al. (2004) Scattered Elements In Boreal Forests. Moscow: Nauka. (in Russian).

31. Perel'man, A. (1979) Moscow: Vysshaya shkola. (in Russian).

32. Pourret, O. et al. (2007) Organic complexation of rare earth elements in natural waters: evaluating model calculations from ultrafiltration data. Geochim Cosmochim Acta, https://doi.org/10.1016/j.gca.2007.04.001.

33. Ramos, S., Dinali, G., Oliveira, C., Martins, G., Moreira, C., Siqueira, J. and Guilherme, L. (2016) Rare Earth Elements in the Soil Environment. Current Pollution Reports, https://doi.org/10.1007/s40726-016-0026-4.

34. Reimann, C., Koller, F., Frengstad, B., Kashulina, G., Niskavaara, H. \& Englmaier, P. (2001) Comparison of the element composition in several plant species and their substrate from a 1500 000-km2 area in Northern Europe. Science of The Total Environment, https://doi.org/10.1016/S0048-9697(00)00890-1.

35. Rodzkin, A., Khroustalev, B., Kundas, S., Chernenok, E. \& Krstic, B. (2019) Potential of Energy Willow Plantations for Biological Reclamation of Soils Polluted by 137Cs and Heavy Metals, and for Control of Nutrients Leaking into Water Systems. Environmental and Climate Technologies, https://doi.org/10.2478/rtuect-2019-0078.

36. Rodzkin, A., Khroustalev, B., Kundas, S., Chernenok, E. and Krstic, B. (2019) Potential of Energy Willow Plantations for Biological Reclamation of Soils Polluted by 137Cs and Heavy Metals, and for Control of Nutrients Leaking into Water Systems. Environmental and Climate Technologies, https://doi.org/10.2478/rtuect-2019-0078.

37. Salam, M., Mohsin, M., Pulkkinen, P., Pelkonen, P. \& Pappinen, A. (2019) Effects of soil amendments on the growth response and phytoextraction capability of a willow variety (S. viminalis $\times$ S. schwerinii $\times$ S. dasyclados) grown in contaminated soils. Ecotoxicology and Environmental Safety, https://doi.org/10.1016/j.ecoenv.2019.01.045.

38. Schlinkert, D., Van den Boogaart, K.G. (2015) The development of the market for rare earth elements: insights from economic theory. Resources Policy, 46 (Part 2), 272-280.

39. Schreiber, A., Marx, J., Zapp, P., Hake, J.-F., Voßenkaul, D., Friedrich, B. (2016) Environmental impacts of rare earth mining and separation based on eudialyte: a new European way. Resources, https://doi.org/10.3390/resources5040032.

40. Singh, A. (2011) Vascular flora on coal mine spoils of Singrauli coalfields, India. Journal of Ecology and the Natural Environment, https://doi.org/10.5897/JENE.9000113.

41. Singh, K., Pandey, V. C., \& Singh, R. P. (2013) Cynodon dactylon: An efficient perennial grass to revegetate sodic lands. Ecological Engineering, https://doi.org/10.1016/j.ecoleng.2013.01.007. 
42. Stille, P., Pierret, M.C., Steinmann, M., Chabaux, F., Boutin, R., Aubert, D., Pourcelot, L., Morvan, G. (2009) Impact of atmospheric deposition, biogeochemical cycling and wateremineral interaction on REE fractionation in acidic surface soils and soil water (the Strengbach case). Chemical Geology, https://doi.org/10.1016/j.chemgeo.2009.03.005.

43. Tang, J., Johannesson, K.H. (2010) Rare earth elements adsorption onto Carrizo sand: influence of strong solution complexation. Chem Geol., https://doi.org/10.1016/j.gca.2007.04.001

44. Thomas, P., Carpenter, D., Boutin, C., Allison, J. (2013) Rare earth elements (REEs): Effects on germination and growth of selected crop and native plant species. Chemosphere,https://doi.org/10.1016/j.chemosphere.2013.07.020.

45. Tlustoš, P., Szàkovà, J., Vysloužilovà, M., Tlustoš, P., Szàkovà, J., Vysloužilovà, M., Pavlìkovà, D., Weger, J., \& Javorskà, H. (2007) Variation in the uptake of arsenic, cadmium, lead and zinc by different species of willows Salix spp. grown in contaminated soils. Eur. J. Biol., https://doi.org/10.2478/s11535-0070012-3.

46. S. Geological Survey, Mineral Commodity Summaries, January 2020 (2020) https://doi.org/10.3133/mcs2020.

47. Vinogradov, A. (1962) Average contents of chemical elements in the main types of igneous rocks of the earth's crust. Geochemistry, 7, 555-571. (in Russian).

48. Wang, L., Liang, T., Zhang, Q., Li, K. (2014) Rare earth element components in atmospheric particulates in the Bayan Obo mine region. Environmental Research, https://doi.org/10.1016/j.envres.2014.02.006.

49. Xiangke, $\mathrm{W}$ et al. (2000) Sorption and desorption of Eu and Yb on alumina: mechanisms and effect of fulvic acid. Appl Radiat Isot., https://doi.org/10.1016/s0969-8043(99)00133-5.

\section{Figures}

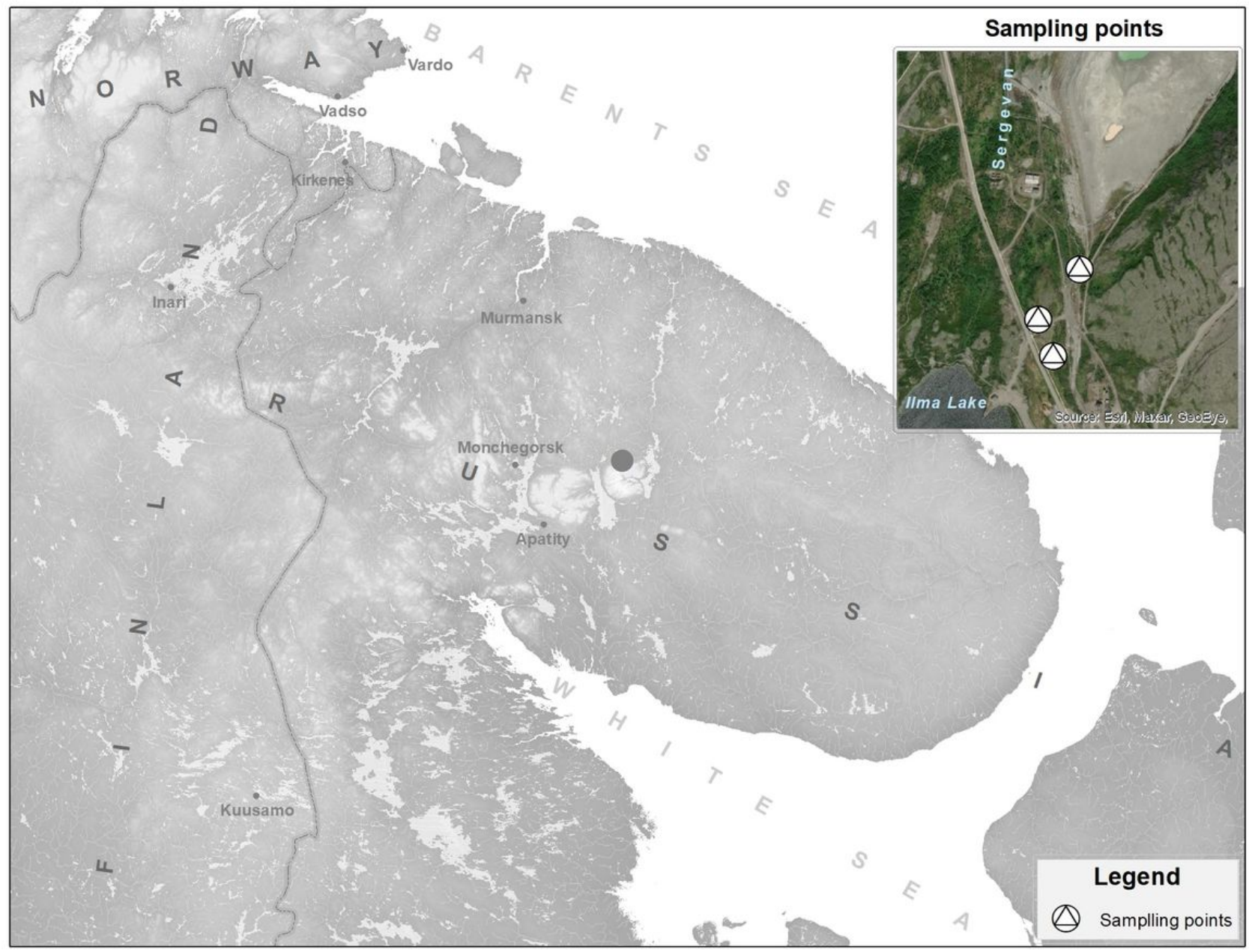

\section{Figure 1}

Sampling locations Note: The designations employed and the presentation of the material on this map do not imply the expression of any opinion whatsoever on the part of Research Square concerning the legal status of any country, territory, city or area or of its authorities, or concerning the delimitation of its frontiers or boundaries. This map has been provided by the authors. 


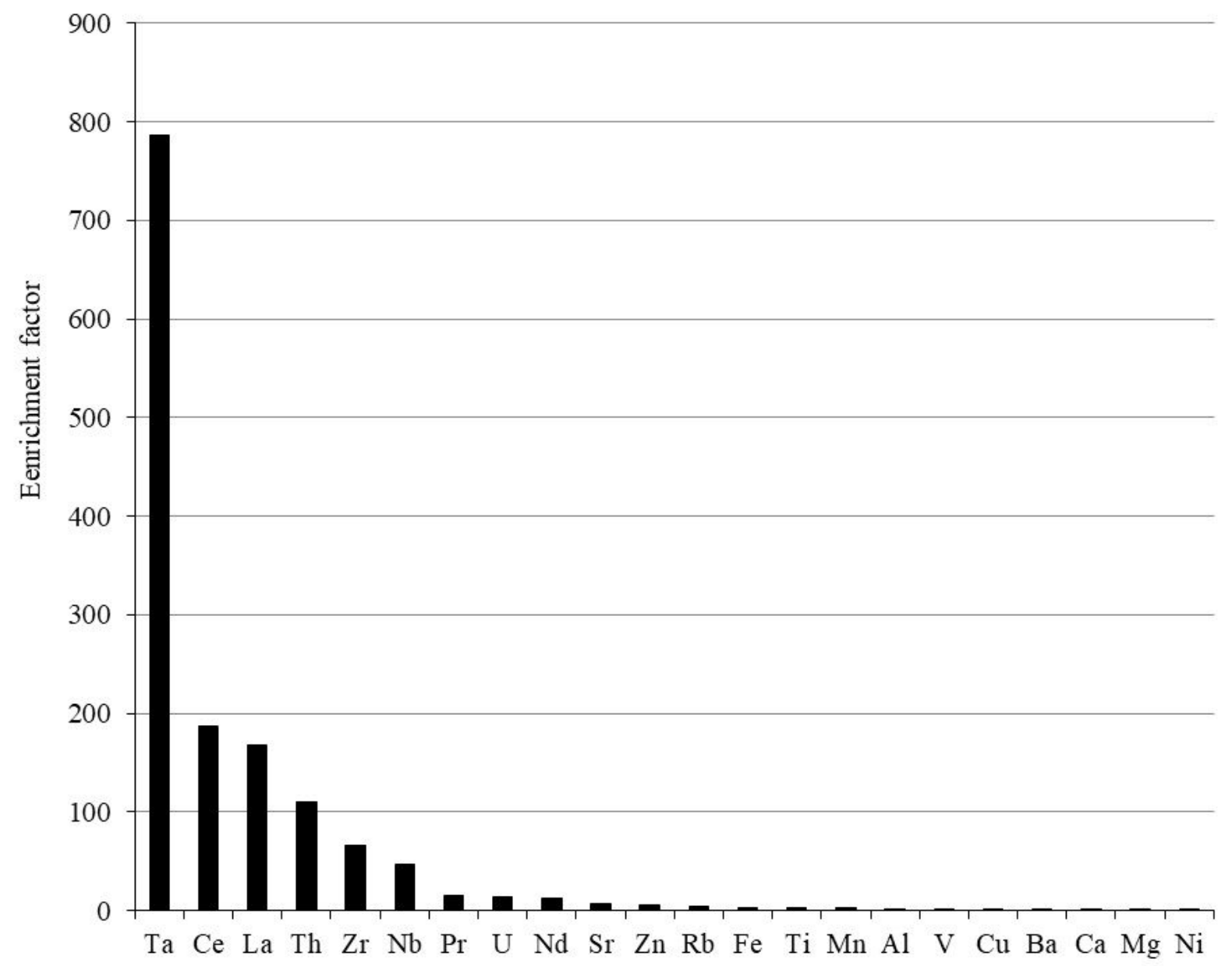

Figure 2

Ranking of ground elements by enrichment factor relative to background/clarke values

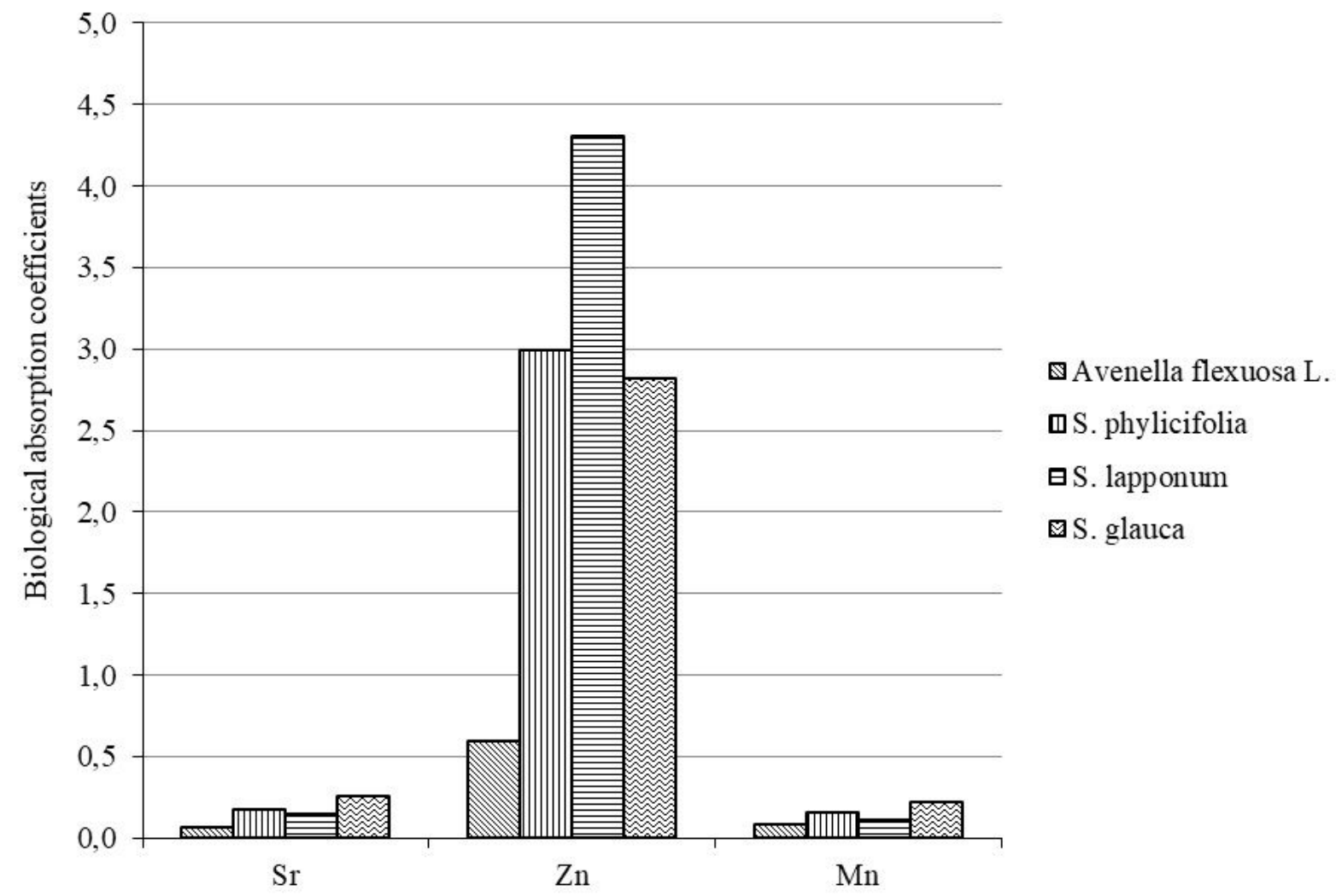

Page 9/10 
Figure 3

Biological absorption coefficients of $\mathrm{Sr}, \mathrm{Zn}, \mathrm{Mn}$

Page $10 / 10$ 